\title{
Integration of Large Scale PV-Based Generation into Power Systems: A Survey
}

\author{
Elyas Rakhshani ${ }^{1}{ }^{\circledR}$, Kumars Rouzbehi ${ }^{2}$, Adolfo J. Sánchez ${ }^{2}$, Ana Cabrera Tobar $^{3}$ and \\ Edris Pouresmaeil $4, *$ (D) \\ 1 Department of Electrical Sustainable Energy, Delft University of Technology, Mekelweg 4, \\ 2628 CD Delft, The Netherlands; E.Rakhshani@tudelft.nl \\ 2 Departamento de Ingeniería de Sistemas y Automática, Universidad de Sevilla, \\ Camino de los Descubrimientos s/n, 41092 Sevilla, Spain; krouzbehi@us.es (K.R.); \\ adolfo.spf@gmail.com (A.J.S.) \\ 3 Department of Electrical Engineering, Universidad Técnica del Norte, Av. 17 de julio s/n, \\ 100150 Ibarra, Ecuador; akcabrera@utn.edu.ec \\ 4 Department of Electrical Engineering and Automation, Aalto University, Maarintie 8, 02150 Espoo, Finland \\ * Correspondence: edris.pouresmaeil@gmail.com; Tel.: +35-850-598-4479
}

Received: 11 March 2019; Accepted: 8 April 2019; Published: 13 April 2019

\begin{abstract}
This paper reports a general overview of current research on analysis and control of the power grid with grid scale PV-based power generations as well as of various consequences of grid scale integration of PV generation units into the power systems. Moreover, the history of PV renewable growth, deregulation of power system and issues related to grid-connected PV systems considering its contribution to various responsibilities like frequency control, virtual inertia capabilities and voltage regulation are discussed. Moreover, various outcomes of the high-penetrated grid with PV power plants such as power quality, active and reactive power control, protection, balancing and reliability under various loading conditions are reviewed and discussed.
\end{abstract}

Keywords: integration of PV plant to grid; large-scale PV power plant; modern power systems

\section{Introduction}

Energy and the matter of renewable resources are critical issues in future power grids. During previous years, energy demand has increased drastically [1] and due to global warming, renewable energy development is crucial in order to reduce conventional fossil power plant harmful emissions [2,3]. Currently, renewable energies being harvested are solar, wind power and hydraulic energy. Facing problems such as climate change and environmental awareness in parallel with huge deregulations in conventional power systems have forced governments to think more deeply about the alternative sources of energy to substitute the traditional sources of energy. These matters have changed the face of the conventional grids and it is expected a rapid deregulation and revolution due to the massive integration of the renewable based generations with stochastic behavior like photovoltaic (PV) systems and wind power. Solar power is becoming more attractive. Solar energy has a huge harvesting potential and based on European Photovoltaic Industry Association (EPIA) reports, the European cumulative PV power was around 29,777 MW in 2010, while as shown in Figure 1, just in 2014, this value for the entire European Union was more than 88,636 MW [4]. It predicts that in 2019 the capacities can be between 121,087 MW to 158,156 MW, which suggests a strong year for the PV industry and the rate of installations will continue to increase through the next 5 years [5]. 


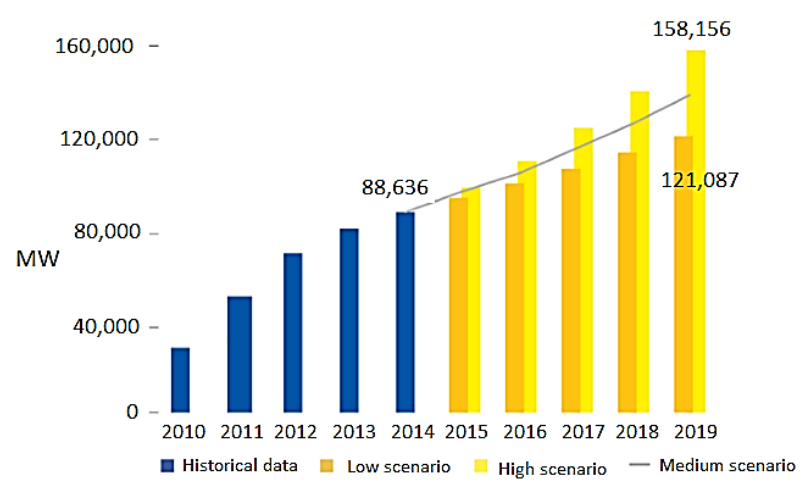

Figure 1. European cumulative solar PV market scenarios until 2019 [5].

PV is a popular source of energy both on the utility's side and for residential home use. PV uses semi-conductor technologies for converting the energy from the sunlight into the electricity. PV, thus, only operates when there is enough energy from the Sun during a day, and it must be mixed with other type of power generation systems to guarantee a continuous supply of the electricity. The PV market is very promising and photovoltaic energy plays a key role on the energy map of various countries. For example, more than about $4 \%$ of the electricity demand in Spain was provided by PV during the last summer. Currently, the largest PV plant is located in the Tengger Desert Solar Park in China, with a total capacity of 1500 MW, followed by the Datong Solar Power Top Runner Base, also in China, and Kurnool Ultra Mega Solar Park in India, both with a capacity of 1000 MW [6].

These ranges of generation will be continuing to increase at least in the next following years and simultaneously make the power grid more complex. One of the most important aspects to take into account in renewable energy is its stochastic nature and its consequences and impact on power grids. Managing this new scenario of power grid full of high-penetrated renewable generations will be complicated and it will be necessary to perform deep research in several aspects.

The impact of large-scale PV based generation units are the focus of many strategic researches on the integration of renewable energy [7,8]. A PV-based power generation unit usually works in the grid connected mode. Nevertheless, unlike conventional generation units, high-capacity PV units, like in the range of multi MW, will have a huge effect on the dynamic performance of the interconnected power system and also will have an important impact on the reliable and stable operation of interconnected systems $[9,10]$. Thus, in the view of the assessment of the grid-connected operation characteristics of the grid scale PV systems, researchers have carried out a vast number of modeling and control studies on dynamic impact and PV system and their contribution on grid support and ancillary services [11,12].

This review paper presents a discussion of large-scale PV power plants and their massive potential to become an important player of the modern future power system. Therefore, benefits, issues, various effects of high penetration of $\mathrm{PV}$ and other requirements to support the correct functioning of PV plants are discussed and reviewed. In Section 2, grid scale PV-based generation unit structures, modelling and control strategies are presented. Modern power systems with the grid scale PV-based generation reviewed and discussed in Section 3. In Section 4, contributions of large scale PV power plants to the grid services such as frequency, reactive, voltage control, balancing and reliability under various loading condition are reviewed. Finally, in Section 5, the paper ends with some concluding remarks.

\section{Large Scale PV Power Plant}

In recent years, the most auspicious usage of PV-based generations has been their integration into the interconnected power grid [13-21]. In [13], a review of existing grid integrated PV-based topologies was presented. Readers should refer to [8,9] for more comprehensive explanations for various PV structures and their technologies. In the category of distributed systems, PV may be broadly classified into four types: (1) very large scale; (2) large-scale; (3) medium Scale, and (4) small scale PV systems. In the small scale PV system, the range of capacities is up to $250 \mathrm{~kW}$. For medium scale, it is around 
250 to $1000 \mathrm{~kW}$. Large scale, it is considered around 1 to $100 \mathrm{MW}$, and for very large scale, the power capacity is higher than $100 \mathrm{MW}$ [14].

\subsection{Structures}

The typical layout of a Utility-Scale PV based system requires several transformers, PV inverters and PV arrays (Figure 2). The connection among these elements depends on the topology used by the PV inverter. Generally, two topologies are used for connection of the PV systems to internal grid of the power plant: central and multistring inverter (Figure 3). In the first structure, only one inverter is used to connect a PV array with the transformer. Commonly, this has a single stage of conversion (DC-AC). Meanwhile, the multistring inverter, has two conversion stages (DC-DC and DC-AC). Commonly, the last topology interconnects one string of PV panels to the internal grid AC grid of the power plant [14].

According to an in depth comparison developed by Cabrera et al. [14], the central inverter is the most used topology in large scale power plants. The main advantages of this topology over the second one are: (i) competitive cost, (ii) robustness, (iii) low maintenance, and (iv) a reduced number of inverters in the field. However, the multistring inverter is used commonly to enhance the control of the maximum power point. This could be necessary when the power plant is located in irregular surfaces.

Moreover, this topology is used for each PV string, so the number of inverters used increases in comparison with a power plant that uses only central inverter. For instance, the Long Island PVPP with a rate of $37 \mathrm{MW}$ uses 50 central inverters. Meanwhile, the Veprek PVPP with a similar capacity uses 3069 multistring inverters According to Massi Pavan et al. [15], and a central inverter configuration has $1.5 \%$ less efficiency than a multistring one. However, the cost for the installation and maintenance of the second one increases by $60 \%$.

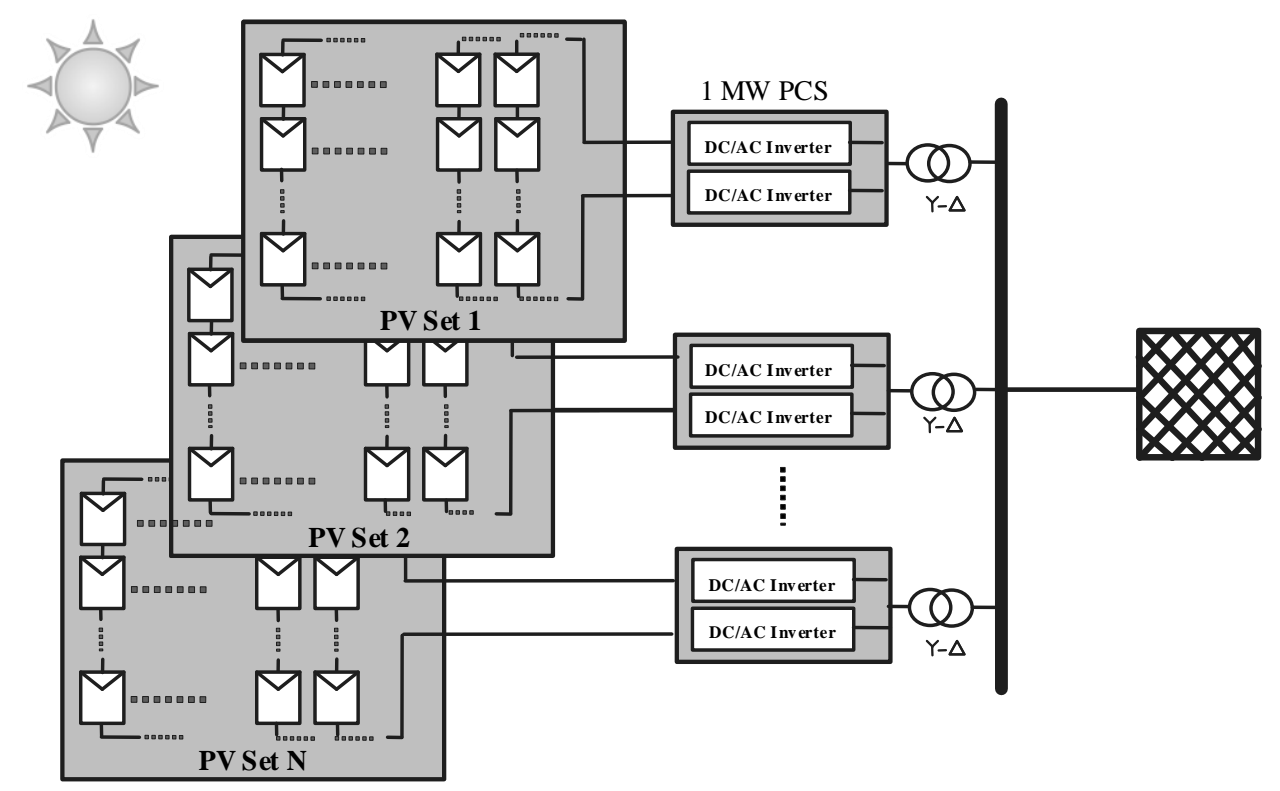

Figure 2. A grid scale PV-based generation unit. 
(a)

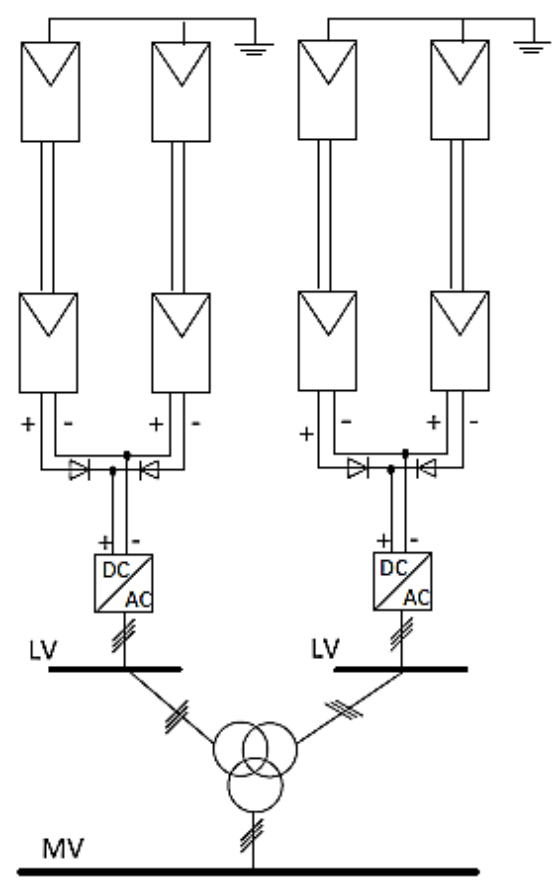

(b)

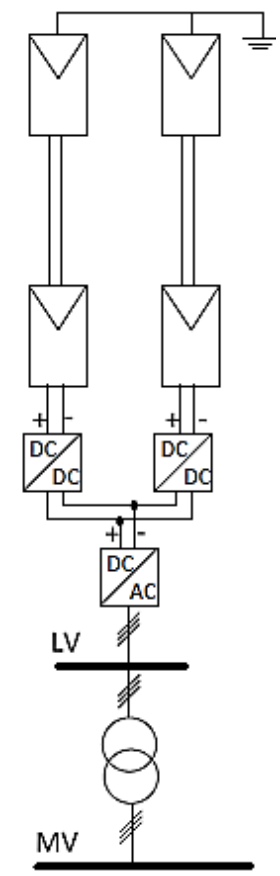

Figure 3. PV inverter topologies: (a) Central PV inverter; (b) Multistring PV inverter.

\subsection{Characteristics of Grid-Connected PV Systems}

Based on various works [21-28], the most important characteristics of PV systems and related grid codes are:

- The PV-based generators together with inverters will be connected in a parallel structure to the power grid, and loads will be supplied properly when the power grid is accessible. As reported in $[2,6,29]$, the produced power by the PV generation will decrease the apparent load, and then the excess energy flows into the power grid.

- Most of the current PV-based inverters don't have any capabilities for providing any type of reactive power/voltage support. PV systems, usually must work at unity power factor and the utility is responsible for VAR requirements.

- Based on regular standards like IEEE 1547, upon the deviations of frequency/voltage grid from their standard ranges, the inverter has to be automatically isolated from the power grid until normal conditions return.

- Geographical factors, location of PVs and factors related to the environment are important characteristics to be taken into account for PV systems. All of these factors can be divided into two periods: (1) day-time and (2) night-time. During the day-time period, PV systems will have to deal with weather disturbances such as clouds and effects of the temperature on the efficiency of the system. Cloudy weather may considerably decrease the net radiation and may cause a fast variation in the output of a PV system. During night-time, the PV system is not collecting energy, which means the output power from the PV systems will be zero. However, the PV system may have a battery energy storage system (BESS), which can provide, for a while, energy to the grid. The Transmission System Operator (TSO) will be informed beforehand if the PV system has or not BESS as well as the possible night-time energy the PV system can deliver or not to the grid.

- It is quite hard to have a good capability to dispatch ancillary services of PV systems without considering additional energy storage devices.

- There is a lack of coordination between PV resources and other conventional plants. Management of reactive power for related feeders is not properly designed for very high PV production. 


\subsection{Modeling and Control of Large-Scale PV Plant}

Dynamic behavior of PV generators, especially with high grid penetration, is different from the conventional generation unit responses. Therefore, it is crucial to find an appropriate model for analyzing the effects of grid scale PV-based power generation on the dynamic stability and oscillations of a large power grid. Generally, grid-connected PV systems are based on core device modeling, which will reflect the characteristics of the PV modules and inverter control [30]. One of the most used corebased models applied for power system analysis is presented in [31]. The schematic design of this model is shown in Figure 4., where $I_{P V}$ is the control variable and is calculated at each time step as the sum of $I_{P V}$ at the previous step, $\Delta I_{P V}^{M P P T}$ reflects the actions of the MPPT, $\Delta I_{P V}^{I r}$ represents the impacts of variations in irradiance and $\Delta I_{P V}^{V a c}$ represents the influence of any sudden variations in AC grid voltage.

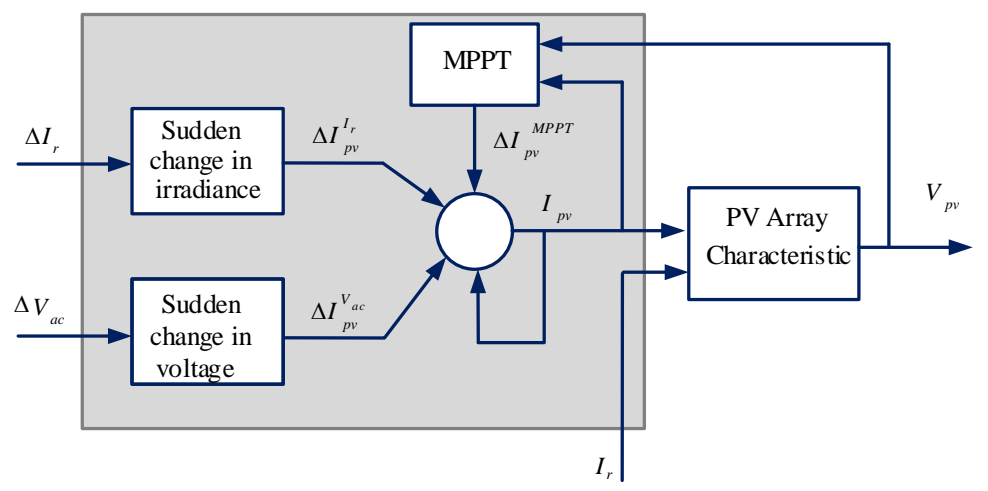

Figure 4. A generic method for PV generation.

In some of the works, solar PV power plants are modeled as static generators [32-34], neglecting the variations of the power output from the PV system. The analysis of possible impacts of output power fluctuation of PV systems with a detailed model is addressed in [32]. For simulation of a grid scale interconnected system, usually, a simplified model or models based on transfer functions are applied [10,33]. Moreover, it should be noted that when a large-scale PV system acts as a renewable power plant, it is very important to find a criterion for selecting the usual patterns for PV output power during each specific season for using the analysis related to system power flow to show carefully the influences of variations on the power grid [35]. The simulation of large system dynamics using a single converter equivalent is adequate for most studies.

Regarding the control of the PV system, several MPPT approaches have been reported in the literature. Numerous MPPT algorithms are explained and discussed in [16-19] focusing on duty cycle control in DC/DC inverters. The main methodologies used for MPPT are: the open circuit voltage approach, constant voltage (CV), incremental conductance (IC) method, ripple-based method and the perturb and observe (called $\mathrm{P} \& \mathrm{O}$ ) technique [20-23] and $[25,26]$. These MPPT techniques differ from each other in several aspects such as simplicity, required measurements, convergence speed, effectiveness, cost and parameterization. $\mathrm{P} \& \mathrm{O}$ and IC techniques are the most widely used. The $\mathrm{P} \& \mathrm{O}$ algorithm works by perturbing the array terminal voltage. It is based on the observation of the sign of the equation $d P / d V_{P V}$. The perturbation is done periodically and the output power of the PV system is compared with the obtained values form the previous cycles $[23,25,26,31]$. If the power increases $d P / d V_{P V}>0$, the control system changes the operating point of the system in that direction. If $d P / d V_{P V}<0$, the operating point has changed in the opposite direction. This algorithm continues until it reaches the MPP. When the system is close to its MPP, then the output power oscillates around the maximum value. This issue might bring some power losses in the PV system. The model schematic shown in Figure 4 uses $\mathrm{P} \& \mathrm{O}$, but in this case $I_{P v}$ is adjusted for the MPPT.

The incremental conductance (IC) method is another approach which due to its high tracking accuracy at the steady state is widely used for different applications. In this approach there is a good flexibility to deal with rapidly changing atmospheric conditions [23]. This algorithm works according 
to the observation of the equation $d I_{P V} / d V_{P V}+\frac{I_{P V}}{V_{P V}}<0$ which has to be held at the MPP value, while $I_{P V}$ and $V_{P V}$ will be the current and voltages of the PV array. Therefore, the MPP can be easily tracked with comparing the instantaneous value of the conductance $I_{P V} / V_{P V}$ to the incremental conductance $d I_{P V} / d V_{P V}$. Thus, as soon as the MPP has been reached, the operation of the PV system will be maintained at this point and the perturbation procedure will be stopped except if another change happens in $d I_{P V}$.

Inside the DC/AC converter, a PWM-based control technique is used for regulating the amount of exchange of the active power and the reactive power between the PV-based generation and the rest of the grid [20]. The DC generated power coming from a PV array can be reflected as real power injected into the power grid. MPPT control will be managed by DC/DC part and it will depend on irradiation and environment conditions. By means of PWM control in the DC/AC part power quality issues and grid synchronization will be done. Active and reactive powers will be calculated as shown in Figure 5 . In order to utilize overall control, two main procedures such as voltage control and the active power control considering DC voltage values in DC bus will be used [34].

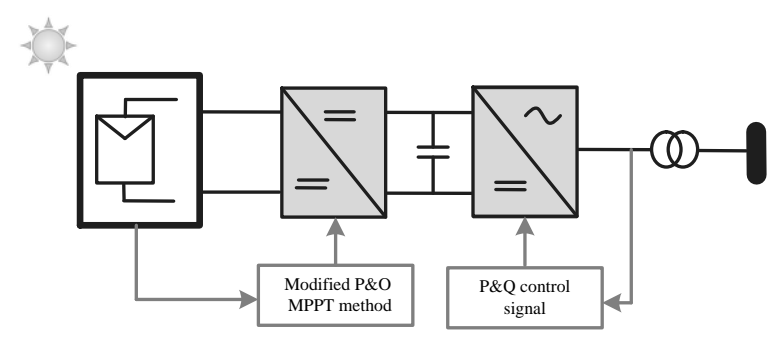

Figure 5. Schematic diagram of a two-stage grid connected PV system.

\section{Modern Power System with PV Systems}

Advances in power processing and control systems, widespread deregulation of power markets with strategic importance dispensed to power supply securities, especially in the last decades, is leading to a new restructuring of electrical power systems. This scenario is moving from a centralized approach to different flexible distributed generation patterns, which has resulted in what are broadly known as modern distributed power systems (DPS) [36].

\subsection{Conventional Power System}

In conventional power system, the utilities were mostly owned by the government. In the other words, the traditional power system was a kind of vertically integrated utility (VIU) structure which holds and operates the main part of the physical assets, including most of the generating units and transmission lines. The utility has control over all generators and by using optimal power flow can re-dispatch to respond to any changes. This monopolistic situation is not fair and with a huge increment in the number of distributed generators (DG), a new restructure and deregulation was necessary for power systems $[37,38]$.

\subsection{Power System Deregulation}

In a competitive electrical grid environment, the VIU does not exist anymore and therefore, the new competitive scheme will be full of generation companies (GENCOs), distribution companies (DISCOs) transmission companies and independent system operators (ISOs) [37] and [39-41]. In this new competitive environment, offering the highest quality electricity and ancillary services is very important.

Services such as operating reserves, reactive or voltage regulation and active power/frequency regulation will be extremely essential for supporting renewable-based power integration. This is especially critical with the integration of intermittent resources of energies [42-46]. 


\subsection{Distributed Power System}

Distributed power systems (DPS) are devoted to customer load supply, which are geographically distributed in an inherent manner, by using distributed generators and energy storage systems spread among distribution networks. Power processing capabilities offered by power electronics have opened new possibilities in the control of DG, which allows implementing ancillary services oriented to compensate the drawbacks of conventional generation units and to improve the dynamic performance of the electrical grid. Among the benefits endorsing DPS [47], it can be highlighted in their capability to:

- Decrease the weaknesses of the electrical power grid.

- Support sufficient standby generation for improving the system reliability.

- Enhance the regulation mechanism and also for stability of the conventional power grid.

- Decrease the environmental impact of power generation.

- Offset the costs of properties of new transmission system schemes.

It is also worth mentioning here that DPS reduce transmission power losses, as well as the length and total number of transmission lines which have to be built. From the point of view of controllability, DPS allow drawing more flexible and adaptable power systems.

\subsection{Operation and Regulation of DPS}

Despite of their unquestionable potential, distributed power systems (DPS) still face important challenges in several areas before becoming a widespread reality. The growing use of distributed power units based on renewable sources of energy will gradually move toward a highly stochastic scenario that eventually might have a huge effect on the online balance in power exchanges, paving the way for the extensive usage of distributed energy storage systems [48-51].

Today, applying energy storage systems with photovoltaic systems is promising and a lot of attention and various studies are being performed in this field. Therefore, an encouraging research concept which opened new windows in the field of hybrid RE/ESS generation system is the concept of virtual inertia (VI) and virtual synchronous generator (VSG) [52-58]. In the VSG concept, a short term energy storage system should be added next to converters of renewable-based power generation systems. A suitable coordination mechanism and a proper control system between the converter and storage device is essential [53]. As shown in Figure 6, VSG presents a solution in which the inverter can be controlled in a way that it will behave as a normal synchronous generator.

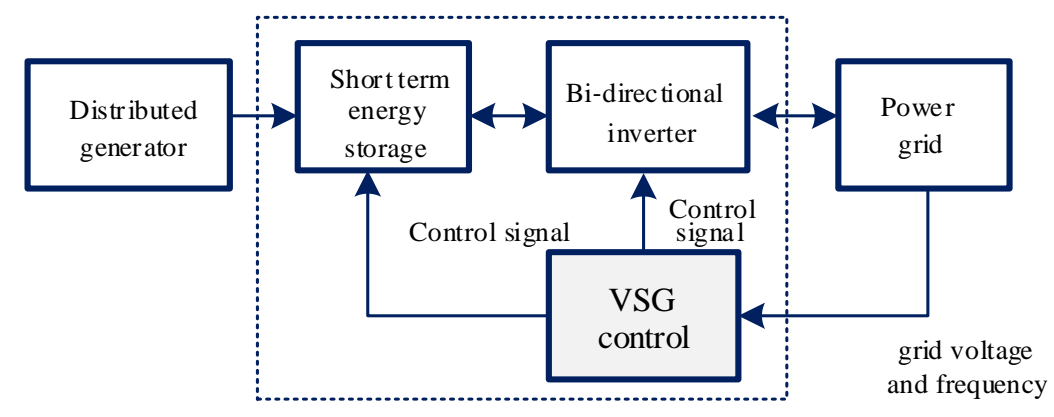

Figure 6. Principle of the VSG.

In modern power system, application of advanced power electronics, FACTS equipment and HVDC systems are becoming more important [59-62]. Moreover, the regular use of different DC line applications may be estimated in the future to fulfil the needs of a deregulated modern power grid [61].

In addition to the exigencies of large-scale integration of DGs, power systems are required to operate under the intensive and competitive conditions set by the deregulated electricity market. This results in a more and more complex operation scheme that forces DPSs to work very close to their limit stability. Thus, it is necessary to make an intensive research effort in this field to apply advanced 
control methods and new concepts, like active management of distribution networks and smart grids, to enable an efficient and reliable operation of DPS [63-68].

\section{Contribution of Large PV Power Plants to Ancillary Services}

Large PV power plants have vast potential to become an important player in the future power system and studies in this field are quite meritorious. In this part of the paper, the typical effects of contributed grid scale PV plants in the grid will be investigated and reviewed.

\subsection{Active Power and Frequency}

PV-based power generation systems have essentially a different nature compared to conventional synchronous generators. PV-based units have stochastic behaviors under various conditions without inertia and dynamic behavior of this kind of generators is subjected by the features and control methodologies used for their power converter parts [69]. Under normal conditions, PV generation has a positive effect on power system behavior. However, in some conditions like cloudy environments and fault contingencies, if the total size of a PV system is large enough, frequency problems may arise at the interconnected power systems [70]. Until now, FACTS controller or PSS, static VAR Compensators and STATCOMs are proposed to improve the power system behavior which may not be always economic [71,72]. It is worth mentioning that the location, degree of penetration and the manner of dispatching the existing conventional generators have a considerable effect and based on these factors the PV plants may have beneficial or detrimental effects on the system. In some cases with adverse effect of PVs, it is recommendable to keep the critical synchronous generators in service, as well as the SVCs for adequate damping of low frequency oscillations [69]. Alternative power generation sources like $\mathrm{P}$, have a great potential for damping the oscillations in a large power system. Even a single PV-based generating system located at the weakest bus of the grid can still enhance the system loading margins [73].

The damping can be introduced through the high power converters that used as interfaces to the network [73-75]. Essentially, the AC generation units which are coupled with gas turbines must operate the electric power at a synchronous frequency. Moreover, in the distributed generators, the power electronic interfaces must act as a frequency changer as well, that change the DC power (for example, in PV) to the utility standard of 60 or $50 \mathrm{~Hz}$. Bidirectional control and unidirectional control are known as two general methods for the PV contribution on active power/frequency services (Figure 7).
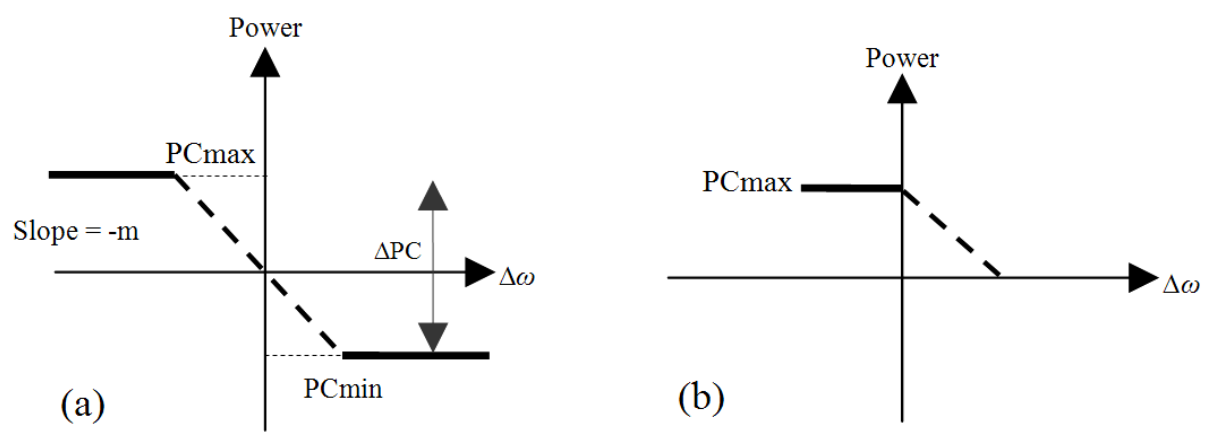

Figure 7. Power control for DGs: (a) Bidirectional; (b) Unidirectional [75].

In the bidirectional method, plant installations and various energy storage technologies will be required to act as a reserve most of the time. However, in unidirectional method, the DG will be acting only in under or over frequency conditions. For example, in the unidirectional method with DGs that just works in its maximum power output, they can contribute in over-frequency conditions by reducing their output power [75]. Applying a coordinated advanced control for PV system in automatic generation control (AGC) will lead to an interesting research field in load-frequency control services $[76,77]$. AGC or load frequency control (LFC) is essential in power system stability and 
control analysis. The main goal of the AGC is to eliminate any mismatches between generators and load demand and its concepts are well-known [38-42]. With the increasing trend in displacing the conventional power plants with renewable plants, effects in frequency control will come into sight. Applying various intelligent control methods like fuzzy, neural network and observer methods will be useful for more flexibility [78,79].

Generally, when a photovoltaic plant stops producing, a conventional power plant will try to replace its place in the electricity grid. This situation will occur in case of a sudden change in irradiation, if the rate of irradiation drops is within certain limits such that there is enough time for governors to respond to it and otherwise in a worst case scenario where a UFLS relay may discard some loads. The frequency relay will activate when the frequency reaches a critical value around $59.7 \mathrm{~Hz}$ [80]. During a fault condition, the response of the PV-based generation units will not show oscillations. This is due to the fact that they do have any mechanical parts and therefore they settle down much faster than conventional generators [80].

\subsection{Rotor Angle Stability}

It should be noted that the oscillatory stability is related to the categories which is called rotor angle stability. Generally, oscillatory instability in low frequency ranges will be caused due to the lack of enough damping torque. This damping in conventional generation is primarily given by the damper winding of machines [81]. Generally, there are two types of oscillatory instability, local and global. Local instabilities will involve a minor area, and typically are due to rotor angle oscillations of each generator against the other part of the system. This oscillations are usually called local plant mode oscillations $[27,38]$. Global oscillations are usually caused by interactions between major groups of generators that are usually expanded in a very large interconnected area. Global oscillations will have widespread effects and it may lead to some partial or full black out in the system. In such scenario, a group of generation units in one area will swing against another set of generation units in the neighbor area. These issues are known as inter area oscillations. Application of HVDC links in parallel with AC links can improve these oscillations [62].

Based on eigenvalue analysis, a system with PV generators will improve dynamic responses by shifting the critical modes to the left half plan and can enhance the dynamic stability of the interconnected power grid by adding more damping over critical modes [27]. In several reports the local and global oscillations can be improved using different technique for PV plant control. As reported in in [82], the POD at PV is designed by using wide-area signal. The damping ratios of the local modes are slightly increased by the integration of POD at PV, while on $[83,84]$ the global modes are improved for systems with high penetration of PV power plants.

In case of small signal stability analysis for PV effects, there is a limit on the operation of the PV based power generation, as far as the system oscillation stability is of concern [85]. The influence of the PV-based penetration on the grid oscillations and its dynamic stability will vary according to the changes in the system operating's condition, which is due to the effects of damping torque impact from the PV system which can be positive or negative. The most serious operating condition for the PV-based power generation unit will arise when the sign of the damping torque's contribution of the PV system is changing [83-85].

\subsection{Reactive Power and Voltage}

The existing interconnected grid is not completely designed for large scale support of interconnected PV and any kind of change in voltage limits during the high solar irradiation is possible. A possible solution for reducing the voltage rise in the feeder, is to operate PV-based generation units with the ability of providing reactive power [86]. In addition, in the case of voltage collapse the inverter has to be able to support sufficient reactive current and stabilize the grid within some time frames defined by grid codes. It should be noted that, the total power generated by the PV generation units follows carefully the pattern of irradiance (due to the MPPT control). Considering the 
fact that, replacements of conventional generation units with PV-based generations will result in a decrease of the total inertia of the interconnected power grid. In the case of voltage stability, for the PV generation units which are not equipped with proper voltage controllers, the connected bus voltage will oscillate more during the periods of severe changes in irradiance, keeping in mind that fluctuations may become much more significant with higher penetration of the PV-based generation [87].

There are relationships between the profile of the system voltage and the maximum penetration rate of a PV network. In fact, the voltage may increase beyond the standard level and the larger amount of power flow produced by DGs at various points of a network may disturb the voltage regulation of the system, especially when a PV-based generator unit is located near the end of a feeder $[88,89]$. The voltage analysis case studies clearly illustrate the voltage sensitivity of a PV neighborhood to PV penetration rate, load variations, and the connection point of the PV cluster on a feeder [88]. That is why the location of RE generators, sizing and configuration of the power system are very important in the case of power quality assessment. Operation of the PV systems at leading power factor with the possibility of absorbing the reactive power is one of the known solutions for compensating this kind of effects [89]. It is worth mentioning that the problem of voltage in rural lines is more than in a meshed network in large cities. This is due to the fact that the distribution line impedance is the key parameter which has more effect on voltage rise [90]. In fact, in a large power grid, if the size of penetration and distribution of PV is well designed according to the grid topology condition, the PV usage as a DG has a positive effect on voltage profile, reliability and loss reduction in a very long distribution line [91].

\subsection{Quality and Protection}

Grid-connected PV systems will have several effects on voltage quality and its control. Since PVbased power generation systems are connected through electronic power converters, they will produce harmonics in the grid but due to current advances in inverter technologies, the harmonic distortions will have an acceptable range. Mainly, the PV effects on power quality and losses reduction are linked to the installation location and the size of the PV system that must be adjusted carefully [27]. In fact, if the PV system is coordinated in a correct manner, various positive effects could be achieved for a distribution system in terms of reliability and quality. For example, a DG can be used as a generation backup during contingencies. In an online system with a high level of PV penetration, it is possible to supply customers during the interrupted situation by transferring the power to other feeders with DGs via switch operation [91,92].

The proper location of the large PV system and loading conditions have considerable effects on the security of the network. It is very important to check the time when the heavy load conditions match with the maximum output generated by PV power plants since it may increase the load level of some lines which are already heavily loaded [93]. Application of intelligent methods like genetic algorithms to obtain the most optimum location and the most suitable size of PV and the application of capacitor banks in the system for minimizing the losses of the system are also interesting topics [94]. The solar penetration can enhance the damping perfectly when operated at 0.9 lag. This might lead to the conclusion that reactive power support coming from the PV systems could be helpful for the damping of oscillations [95].

In the case of power system protection, it should be noted that with a huge increment of generation on the feeder, over-current flows in various parts of the feeder will occur. Thus, problems such as sympathetic tripping and other type of over-current disruption arise. In general, over-current protective devices are coordinated by setting the pickup currents to sense the expected fault currents related to the highest impedance fault. By adding a DG unit between the protection component and the fault, the sensitivities in the feeder protection can be reduced. The DG units maintain the voltage profile through the up line part of the feeder and therefore the current which is seen by the protective components and also the level of the sensitivity of relays can be reduced and for complete detect-ability, it needs to sense the faults in a closer place $[96,97]$. As reported in [98], if there are faulty nodes in the 
system, a novel algorithm to deal with such issues is presented. Their proposed multi-scale filtering algorithm, which is using local information, can withstand both faulty and Byzantine nodes.

In the case of security, the conventional power system is a passive network, it means that the power exchanges in most the radial distribution system will have single directions. In the case of modern power grids with various PV distributed generators, the power flow has bi-directional characteristics. Therefore, it is necessary to redesign power systems in order to coordinate PV systems with the original relay system $[29,70]$. Injection of inverse power from downstream points will not be detected by traditional fuses because of their design and capabilities. In case that the islanding detection by relay fails, then the inverter might remain in the service (on-line) and cause severe threats to the components, especially demand side equipment.

The electrical distribution utilities have to fulfill some important restrictions about the power quality of the electricity delivered to its customers. One of these restrictions is related to the voltage quality, like if the voltage gets a too high value in PCC, especially during the noon of summer days, PV systems could be stopped and should automatically be disconnected from the grid. Generally, PV systems are equipped with under-over voltage relays and when the value of voltage in the PCC reaches a setting above the over-voltage relay, the photovoltaic unit will be disconnected, a condition commonly named "output restriction" [90].

\subsection{Power Balancing}

Thermal power plants when running in frequency control mode, will incur some additional costs. This is due to the fact that the related generation should be matched with load variations. However, when a high level of renewable-based generation is integrated into the existing power system, usually an additional source of variation will be added to the system which is already concerned with the changes of its demands. It should be noted that the whole power grid must be balanced instead of balancing each individual load or resource [6]. The main question in high penetration of renewablebased power generation is to which extent the balancing uncertainties can be increased? Obviously it became clear that most of the variations at the output of PV system or in wind units are mainly unrelated to the loads. Thus, this might indicate that an additional source of uncertainty can be introduced by PV power. The total thermal power plant output is approximately a "sum of squares" of two separate parts [98]: total variability of electricity demand and total variability in renewable energies outputs. Demand prediction techniques [99-102] and time-series data analysis $[35,103,104]$ for better prediction of DG outputs will be useful it these fields, so it is preferable to maintain some reserve to recover from probable trips of conventional power plants.

\subsection{PV Power Plants and Reliability of Power System}

When renewable energies displace a significant amount of conventional power plants, commonly an additional conventional power capacity is required to keep the system supply secure [6]. This added plant margin will be required, especially when the output of renewable generation are at its maximum level.

The annual ratio of continual output energy produced by a power plant is known as a capacity Factor. This factor will be a very useful guide for knowing the probability that the generation units will be available for contributing against load demand. However, in the case of renewable-based power plants, especially during peak load demands, renewable energies sources are not capable of providing the same level of reliable power as conventional generators but they are still capable of providing their contribution of part of the loads. This ability of renewable energies resources is known as the capacity credit and is the amount of load produced by renewable energies plants, see [98,105]. During the peak loads, in addition to the operating reserve, some system margin is required and this will be affected by the level of renewable energies penetration [6]. In addition, in some periods that the available output from the renewable resources exceeds demand or in a situation that it cannot be accommodated by the transmission system, it is necessary to discard energy from renewable energies plants. This 
output control can be done by pitch angle control in wind turbines or inverter control in PV power plants. However, it will take some economic penalties for renewable energies plants which become increasingly important at high penetrations [106-111].

Combination of different renewable-based sources such as PV and wind is very helpful for the reliability of the system [95]. Furthermore, it should be noted that applying a PV-based generation unit according to the MPPT for a fixed amount of the maximum power might reduce the flexibility of the unit for proper power regulation [106]. As a solution to increase the reliability, the PV system can operate with a pseudo-maximum power point instead of MPPT. This idea is shown in Figure 8, where $\mathrm{P}_{1}$ represents the maximum possible power from the MPPT algorithm and $\mathrm{P}_{2}$ represents the false or pseudo-maximum power point that has to be tracked by the system. The provided reserve power will be the difference between those points.

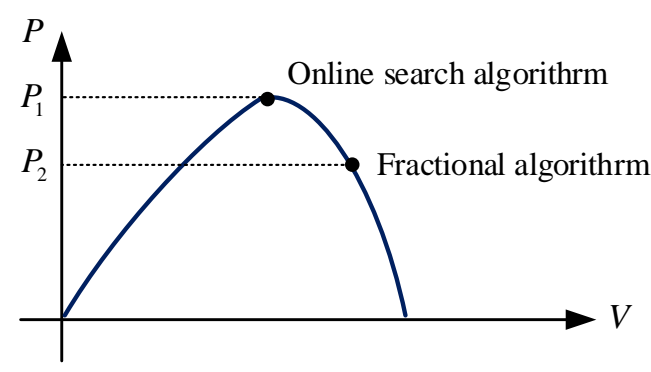

Figure 8. Combination of algorithms for tracking different operating points on the $P-V$ curve.

\subsection{Contribution to the System Inertia}

Research activities in this area started 10 years ago. There were always discussions about the meaning and proper definition of virtual inertia. In [112] a comprehensive study about definitions of fast frequency response and virtual inertia was presented. In this reference, synthetic inertia from the perspective of a transmission system operator was discussed and then compared to a fast frequency response based on frequency deviation of the system. According to this definition, better understanding of these terms for different applications can be obtained. Discussions on virtual inertia concept, control and prototype were the main accomplishments. Figure 9 shows the key landmarks on the virtual inertia concept:

- First publication (a conference paper)

- First paper to show experimental results

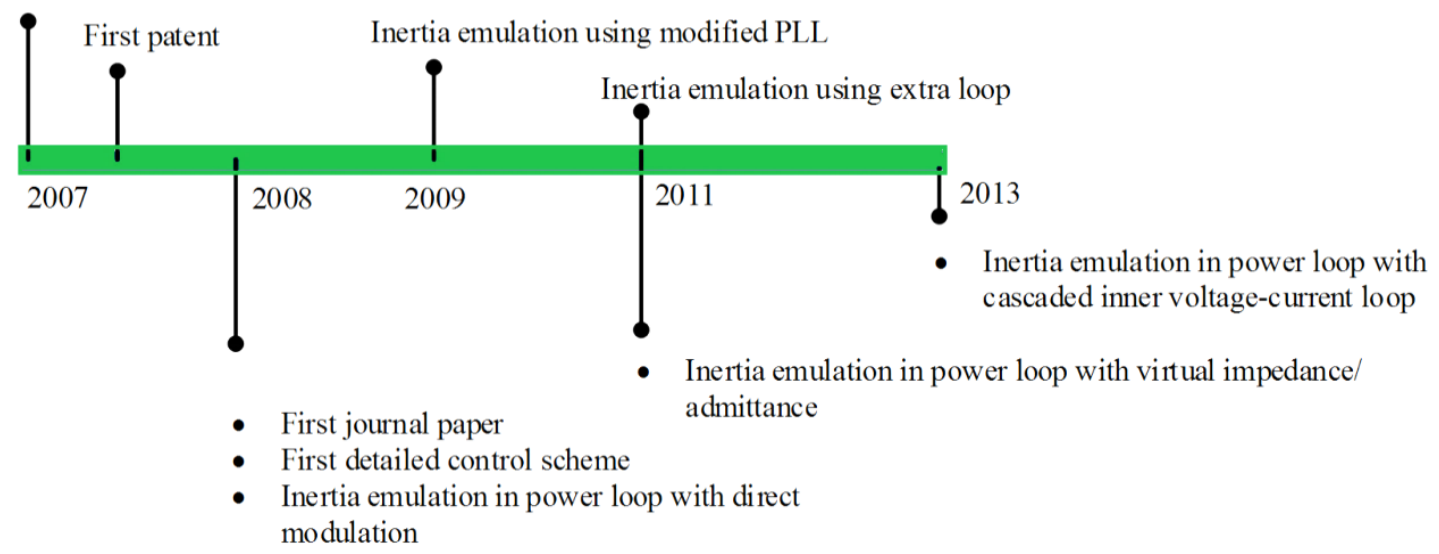

Figure 9. Important landmarks of the virtual inertia concept.

The first publication that initiated the idea of synchronous generation emulation control was a manuscript by Beck et al. [113], where the concept and experimental results were shown. A patent 
registered after the mentioned article, by the same authors named this system a virtual synchronous machine (VISMA) [114].

The first article was coauthored by Iravani [115]. A detailed control scheme indicating how this concept can be implemented was presented in this paper. Active power control loop was in charge of the inertial characteristics. PLLs with inertia emulation capabilities were first reported by Wesenbeeck et al. [116]. They named their concept a "virtual synchronous generator".

Emulation of synthetic inertia by means of an extra loop was started in [117] by Vrana et al. The main concern of this method is its practical implementation, as it is based on a time derivative operator. The main advantage of this method is its straightforwardness.

Later, an inertia emulation and virtual admittance combination developed named synchronous power controller (SPC) was described [118]. The insertion of the virtual admittance in the controller conveys several advantages, such as accurate power sharing, grid current control, and ease of implementation.

To avoid direct modulation in the inner- loop an alternative method was proposed. The first journal paper was authored by D'Arco et al. [119]. Figure 9 shows the first publications of each type, although a number of studies were published around the same time. For example Weiss et al.'s "synchronverters" [120], and Ise et al.'s "Ise lab" [121].

\section{Conclusions}

This paper has presented a comprehensive review of the recently published works in the area modern power system control and analysis with integration of large-scale PV renewable resources. It was indicated that large-scale PV power plants have a massive potential to become an important player in modern power systems. Benefits, problems, various effects of high penetration of large-scale PV power plants and other requirements to help PV plants work properly instead of conventional power sources in the grid and contribute to ancillary services such as frequency or voltage control was discussed.

Considering the location and penetration level of PV power plants, the manner of dispatching the existing conventional power plant and its configuration, PV plants may have beneficial or detrimental effects on the system behavior. Current power systems are not designed to support high penetration of interconnected PV and to meet the grid codes. Applying smart and online control methods for more coordination between all parts of modern power systems will be necessary.

With more and more penetration of renewable energy resources such as PV plants, the available inertia level of the grid is decreasing significantly. This matter is becoming a critical challenge for this emerging modern power systems control paradigm that should be properly addressed. As discussed earlier, the development of virtual inertia control strategies is a step towards overcoming the issues faced issue. On the other hand, inclusion of battery energy storage systems with PV plants will play an important role. In recent years, the capital cost of battery energy storages has decreased drastically, while their technology, reliability, and the life cycle have all increased significantly. The authors of the current paper believe that hybrid PV/battery plants are another promising solution on the way of addressing the issue of synthetic inertia control and several more faced issues.

Author Contributions: All authors have contributed equally on this manuscript together and all authors have read and approved the final manuscript.

Funding: This research received no external funding.

Conflicts of Interest: The authors declare no conflict of interest.

\section{Nomenclature}

$\begin{array}{ll}\text { AGC } & \text { Automatic Generation Control } \\ \text { BESS } & \text { Battery Energy Storage System } \\ \text { DG } & \text { Distributed Generator } \\ \text { DC } & \text { Direct Current }\end{array}$




$\begin{array}{ll}\text { DISCO } & \text { Distributed Company } \\ \text { DPS } & \text { Distributed Power Systems } \\ \text { EPIA } & \text { European Photovoltaic Industry Association } \\ \text { ESS } & \text { Energy Storage System } \\ \text { FACTS } & \text { Flexible AC Transmission Systems } \\ \text { GENCO } & \text { Generation Company } \\ \text { HVDC } & \text { High Voltage Direct Current } \\ \text { ISO } & \text { Independent System Operator } \\ \text { MPPT } & \text { Maximum Power Point Tracking } \\ \text { P\&O } & \text { Perturb and Observe } \\ \text { PWM } & \text { Pulse Width Modulation } \\ \text { PCC } & \text { Point of Common Coupling } \\ \text { PLL } & \text { Phase Locked Loop } \\ \text { PV } & \text { Photovoltaic } \\ \text { PVPP } & \text { Photovoltaic Power Plant } \\ \text { TSO } & \text { Transmission system operator } \\ \text { UFLS } & \text { Under Frequency Load Shedding } \\ \text { VIU } & \text { Vertically Integrated Utilities } \\ \text { VSG } & \text { Virtual Synchronous Generator } \\ \text { VSC } & \text { Voltage Source Converter }\end{array}$

\section{References}

1. Solangi, K.H.; Islam, M.R.; Saidur, R.; Rahim, N.A.; Fayaz, H. A review on global solar energy policy. Renew. Sustain. Energy Rev. 2011, 15, 2149-2163. [CrossRef]

2. Goswami, D.; Kreith, F.; Kreider, J. Principles of Solar Engineering, 2nd ed.; Taylor \& Francis: Abingdon, UK, 2000.

3. Cabrera-Tobar, A.; Bullich-Massagué, E.; Aragüés-Peñalba, M.; Gomis-Bellmunt, O. Review of advanced grid requirements for the integration of large scale photovoltaic power plants in the transmission system. Renew. Sustain. Energy Rev. 2016, 62, 971-987. [CrossRef]

4. Global Market Outlook for Solar Power 2018-2022, Solar Power Europe Reports. June 2018. Available online: http://www.solarpowereurope.org/global-market-outlook-2018-2022/ (accessed on 30 August 2018).

5. Global Market Outlook for Solar Power 2015-2019, Solar Power Europe Reports. June 2015. Available online: https://resources.solarbusinesshub.com/solar-industry-reports/item/global-market-outlook-for-solarpower-2015-2019 (accessed on 30 August 2018).

6. Biggest Solar Power Plants. Mechanical, Electrical and Electronics Engineers. Available online: https: //meee-services.com/biggest-solar-power-plants (accessed on 30 August 2018).

7. Guerrero-Lemus, R.; Cañadillas-Ramallo, D.; Reindl, T.; Valle-Feijóo, J.M. A simple big data methodology and analysis of the specific yield of all PV power plants in a power system over a long time period. Renew. Sustain. Energy Rev. 2019, 107, 123-132. [CrossRef]

8. Craciun, B.-I.; Kerekes, T.; Sera, D.; Teodorescu, R. Frequency Support Functions in Large PV Power Plants with Active Power Reserves. IEEE J. Emerg. Sel. Top. Power Electron. 2014, 2, 849-858. [CrossRef]

9. Bullich-Massagué, E.; Gomis-Bellmunt, O.; Serrano-Salamanca, L.; Ferrer-San-José, R.; Pacheco-Navas, C.; Aragüés-Peñalba, M. Power plant control in large-scale photovoltaic plants: Design, implementation and validation in a 9.4 MW photovoltaic plant. IET Renew. Power Gener. 2016, 10, 50-62. [CrossRef]

10. Datta, M.; Senjyu, T. Fuzzy Control of Distributed PV Inverters/Energy Storage Systems/Electric Vehicles for Frequency Regulation in a Large Power System. IEEE Trans. Smart Grid 2013, 4, 479-488. [CrossRef]

11. Han, P.; Lin, Z.; Wang, L.; Fan, G.; Zhang, X. A Survey on Equivalence Modeling for Large-Scale Photovoltaic Power Plants. Energies 2018, 11, 1463. [CrossRef]

12. De la Parra, I.; Muñoz, M.; Lorenzo, E.; García, M.; Martínez-Moreno, F. PV performance modelling: A review in the light of quality assurance for large PV plants. Renew. Sustain. Energy Rev. 2017, 78, 780-797. [CrossRef]

13. Nema, S.; Nema, R.K.; Agnihotri, G. Inverter topologies and control structure in photovoltaic applications: A review. J. Renew. Sustain. Energy 2011, 3, 12701. [CrossRef] 
14. Cabrera-Tobar, A.; Bullich-Massagué, E.; Aragüés-Peñalba, M.; Gomis-Bellmunt, O. Topologies for large scale photovoltaic power plants. Renew. Sustain. Energy Rev. 2016, 59, 309-319. [CrossRef]

15. Castellan, A.M.P.S.; Quaia, S.; Roitti, S.; Sulligoi, G. Power electronic conditioning systems for industrial photovoltaic fields: Central or string inverters? In Proceedings of the International Conference on Clean Electrical Power, Capri, Italy, 21-23 May 2007.

16. Koutroulis, E.; Blaabjerg, F. A New Technique for Tracking the Global Maximum Power Point of PV Arrays Operating Under Partial-Shading Conditions. IEEE J. Photovolt. 2012, 2, 184-190. [CrossRef]

17. Karanayil, B.; Ceballos, S.; Pou, J. Maximum Power Point Controller for Large Scale Photovoltaic Power Plants Using Central Inverters under Partial Shading Conditions. IEEE Trans. Power Electron. 2018, 34, 3098-3109. [CrossRef]

18. Jain, S.; Agarwal, V. A Single-Stage Grid Connected Inverter Topology for Solar PV Systems with Maximum Power Point Tracking. IEEE Trans. Power Electron. 2007, 22, 1928-1940. [CrossRef]

19. Lappalainen, K.; Valkealahti, S. Effects of irradiance transition characteristics on the mismatch losses of different electrical PV array configurations. IET Renew. Power Gener. 2017, 11, 248-254. [CrossRef]

20. Ho, M.T.; Chung, H.S.H. An integrated inverter with maximum power tracking for grid-connected PV systems. IEEE Trans. Power Electron. 2005, 20, 953-962. [CrossRef]

21. Du, W.; Wang, H.F.; Dunn, R. Power system small-signal oscillation stability as affected by large-scale PV penetration. In Proceedings of the International Conference on Sustainable Power Generation and Supply, SUPERGEN, Beijing, China, 6-7 April 2009; pp. 1-6.

22. Saez-De-Ibarra, A.; Herrera, V.; Milo, A.; Gaztanaga, H.; Etxeberria, I.; Bacha, S.; Padros, A. Management Strategy for Market Participation of Photovoltaic Power Plants including Storage Systems. IEEE Trans. Ind. Appl. 2016, 52, 4292-4303. [CrossRef]

23. Pouresmaeil, E.; Montesinos-Miracle, D.; Gomis-Bellmunt, O. Control scheme of three-level NPC inverter for integration of renewable energy resources into AC grid. IEEE Syst. J. 2012, 6, 242-253. [CrossRef]

24. Faranda, R.; Leva, S.; Maugeri, V. MPPT techniques for PV Systems: Energetic and cost comparison. In Proceedings of the IEEE Power and Energy Society General Meeting, Pittsburgh, PA, USA, 20-24 July 2008.

25. Ruan, S.-Y.; Li, G.-J.; Ooi, B.-T.; Sun, Y.-Z. Power system damping from real and reactive power modulations of voltage-source-converter station. IET Gener. Transm. Distrib. 2008, 2, 311-320. [CrossRef]

26. Jain, S.; Agarwal, V. New current control based MPPT technique for single stage grid connected PV systems. Energy Convers. Manag. 2008, 48, 625-644. [CrossRef]

27. Brunton, S.L.; Rowley, C.W.; Kulkarni, S.R.; Clarkson, C. Maximum Power Point Tracking for Photovoltaic Optimization Using Ripple-Based Extremum Seeking Control. IEEE Trans. Power Electron. 2010, 25, 2531-2540. [CrossRef]

28. Mehrasa, M.; Pouresmaeil, E.; Pournazarian, B.; Sepehr, A.; Marzband, M.; Catalão, J.P.S. Synchronous Resonant Control Technique to Address Power Grid Instability Problems Due to High Renewables Penetration. Energies 2018, 11, 2469. [CrossRef]

29. Van, T.V.; Visscher, K.; Diaz, J.; Karapanos, V.; Woyte, A.; Albu, M.; Bozelie, J.; Loix, T.; Federenciuc, D. Virtual synchronous generator: An element of future grids. In Proceedings of the IEEE PES Innovative Smart Grid Technologies Conference Europe (ISGT Europe), Gothenburg, Sweden, 11-13 October 2010; pp. 1-7.

30. Ramachandran, V.; Solanki, S.K.; Solanki, J. Steady state analysis of three phase unbalanced distribution systems with interconnection of photovoltaic cells. In Proceedings of the IEEE/PES Power Systems Conference and Exposition (PSCE), Phoenix, Arizona, 20-23 March 2011; pp. 1-7.

31. Feng, L.; Wei, L.; Xue, F.; Shi, T.; Zhu, L. Simulation of Grid-Connected Photovoltaic Power Plant Based on Fastest. In Proceedings of the Asia-Pacific Power and Energy Engineering Conference (APPEEC), Wuhan, China, 25-28 March 2011; pp. 1-4.

32. Tan, Y.T.; Kirschen, D.S.; Jenkins, N. A Model of PV Generation Suitable for Stability Analysis. IEEE Trans. Energy Convers. 2004, 19, 748-755. [CrossRef]

33. Yazdani, A.; Dash, P.P. A Control Methodology and Characterization of Dynamics for a Photovoltaic (PV) System Interfaced with a Distribution Network. IEEE Trans. Power Deliv. 2009, 24, 1538-1551. [CrossRef]

34. Dong-Jing, L.; Li, W. Small-Signal Stability Analysis of an Autonomous Hybrid Renewable Energy Power Generation/Energy Storage System Part I: Time-Domain Simulations. IEEE Trans. Energy Convers. 2008, 23, 311-320. 
35. Dahal, S.; Mithulananthan, N.; Saha, T. An approach to control a photovoltaic generator to damp low frequency oscillations in an emerging distribution system. In Proceedings of the IEEE Power and Energy Society General Meeting, Detroit, MI, USA, 24-28 July 2011; pp. 1-8.

36. Lee, F.C.; Barbosa, P.; Xu, P.; Zhang, J.; Yang, B.; Canales, F. Topologies and design considerations for distributed power system applications. Proc. IEEE 2001, 89, 939-950. [CrossRef]

37. Saez-de-Ibarra, A.; Milo, A.; Gaztañaga, H.; Debusschere, V.; Bacha, S. Co-Optimization of Storage System Sizing and Control Strategy for Intelligent Photovoltaic Power Plants Market Integration. IEEE Trans. Sustain. Energy 2016, 7, 1749-1761. [CrossRef]

38. Lai, L.L. Power System Restructuring and Deregulation, Trading, Performance and Information Technology; John Wiley \& Sons, Ltd.: London, UK, 2001.

39. Kundur, P. Power System Stability and Control; McGraw-Hill: New York, NY, USA, 1994.

40. Rakhshani, E. Intelligent linear-quadratic optimal output feedback regulator for a deregulated automatic generation control system. Electr. Power Compon. Syst. 2012, 40, 513-533. [CrossRef]

41. Rakhshani, E.; Sadeh, J. Practical viewpoints on load frequency control problem in a deregulated power system. Energy Convers. Manag. 2010, 51, 1148-1156. [CrossRef]

42. Rakhshani, E.; Rodriguez, P. Active Power and Frequency Control Considering Large Scale RES. In Large Scale Renewable Power Generation; Springer-Verlag: Berlin/Heidelberg, Germany, 2014; pp. 233-271.

43. Chamana, M.; Chowdhury, B.H.; Jahanbakhsh, F. Distributed Control of Voltage Regulating Devices in the Presence of High PV Penetration to Mitigate Ramp-Rate Issues. IEEE Trans. Smart Grid 2018, 9, 1086-1095. [CrossRef]

44. UCTE Operation Handbook, v 2.5E; UCTE, July 2004.

45. Wang, G.; Ciobotaru, M.; Agelidis, V.G. Power Management for Improved Dispatch of Utility-Scale PV Plants. IEEE Trans. Power Syst. 2016, 31, 2297-2306. [CrossRef]

46. Rebours, Y.G.; Kirschen, D.S.; Trotignon, M.; Rossignol, S. Survey of Frequency and Voltage Control Ancillary Services-Part I: Technical Features. IEEE Trans. Power Syst. 2007, 22. [CrossRef]

47. Corsi, S.; Marannino, P.; Losignore, N.; Moreschini, G.; Piccini, G. Coordination between the reactive power scheduling function and the hierarchical voltage control of the EHV ENEL system. IEEE Trans. Power Syst. 1995, 10, 686-694. [CrossRef]

48. An Agreement Report of Brookings and Hoover Institutions: Assessing the Role of Distributed Power Systems in the U.S. Power Sector., The Brookings Institution Energy Security Initiative, USA. 2011. Available online: http://www.recycled-energy.com/images/uploads/Brookings_Hoover_DPS_study.pdf (accessed on 30 August 2018).

49. Papaefthymiou, S.V.; Karamanou, E.G.; Papathanassiou, S.A.; Papadopoulos, M.P. A Wind-Hydro-Pumped Storage Station Leading to High RES Penetration in the Autonomous Island System of Ikaria. IEEE Trans. Sustain. Energy 2010, 1, 163-172. [CrossRef]

50. Taylor, J.; Halnes, A. Analysis Of compressed air energy storage. In Proceedings of the PCIC Europe, Oslo, Norway, 15-17 June 2010; pp. 1-5.

51. Bhatt, R.; Chowdhury, B. Grid frequency and voltage support using PV systems with energy storage. In Proceedings of the North American Power Symposium (NAPS), Boston, MA, USA, 4-6 August 2011; pp. 1-6.

52. Kang, B.-K.; Kim, S.-T.; Sung, B.-C.; Park, J.-W. A Study on Optimal Sizing of Superconducting Magnetic Energy Storage in Distribution Power System. IEEE Trans. Appl. Supercond. 2012, 22, 5701004.

53. Mehrasa, M.; Pouresmaeil, E.; Sepehr, A.; Pournazarian, B.; Marzband, M.; Catalão, J.P.S. Control technique for the operation of grid-tied converters with high penetration of renewable energy resources. Electr. Power Syst. Res. 2019, 166, 18-28. [CrossRef]

54. Mehrasa, M.; Pouresmaeil, E.; Soltani, H.; Blaabjerg, F.; Calado, M.R.A.; Catalão, J.P.S. Virtual Inertia and Mechanical Power-Based Control Strategy to Provide Stable Grid Operation under High Renewables Penetration. Appl. Sci. 2019, 9, 1043-1058. [CrossRef]

55. Wang, L.; Vo, Q.; Prokhorov, A.V. Stability Improvement of a Multimachine Power System Connected with a Large-Scale Hybrid Wind-Photovoltaic Farm Using a Supercapacitor. IEEE Trans. Ind. Appl. 2018, 54, 50-60. [CrossRef]

56. Chen, S.; Zhang, T.; Gooi, H.B.; Masiello, R.D.; Katzenstein, W. Penetration Rate and Effectiveness Studies of Aggregated BESS for Frequency Regulation. IEEE Trans. Smart Grid 2016, 7, 167-177. [CrossRef] 
57. Bi, D.; Wang, S.; Ge, B.; Yang, X. Control strategy of grid-connected photovoltaic system with energy storage. In Proceedings of the International Conference on Electrical Machines and Systems, Beijing, China, 20-23 August 2011; pp. 1-4.

58. Delille, G.; François, B.; Malarange, G. Dynamic frequency control support: A virtual inertia provided by distributed energy storage to isolated power systems. In Proceedings of the IEEE PES Innovative Smart Grid Technologies Conference Europe (ISGT Europe), Gothenburg, Sweden, 11-13 October 2010; pp. 1-8.

59. Wang, D.; Meng, K.; Gao, X.; Qiu, J.; Lai, L.L.; Dong, Z.Y. Coordinated Dispatch of Virtual Energy Storage Systems in LV Grids for Voltage Regulation. IEEE Trans. Ind. Inform. 2018, 14, 2452-2462. [CrossRef]

60. Hulpin, Y.; Ernst, D. Ancillary services and operation of multi-terminal HVDC grids. In Proceedings of the International Workshop on Transmission Networks for Offshore Wind Power Plants, Aarhus, Denmark, 25-26 October 2011; pp. 1-6.

61. Zhu, J.; Guerrero, J.M.; Hung, W.; Booth, C.D.; Adam, G.P. Generic inertia emulation controller for multi-terminal voltage-source-converter high voltage direct current systems. IET Renew. Power Gener. 2014, 8, 740-748. [CrossRef]

62. Povh, D. Use of HVDC and FACTS. Proc. IEEE 2000, 88, 235-245. [CrossRef]

63. Dai, J.; Phulpin, Y.; Sarlette, A.; Ernst, D. Coordinated primary frequency control among non-synchronous systems connected by a multi-terminal high-voltage direct current grid Generation. IET Transm. Distrib. 2012, 6, 99-108. [CrossRef]

64. Conti, S.; Nicolosi, R.; Rizzo, S.A. Generalized Systematic Approach to Assess Distribution System Reliability with Renewable Distributed Generators and Microgrids. IEEE Trans. Power Deliv. 2012, 27, 261-270. [CrossRef]

65. Stimoniaris, D.; Tsiamitros, D.; Dialynas, E. Improved Energy Storage Management and PV-Active Power Control Infrastructure and Strategies for Microgrids. IEEE Trans. Power Syst. 2016, 31, 813-820. [CrossRef]

66. Podmore, R.; Robinson, M.R. The Role of Simulators for Smart Grid Development. IEEE Trans. Smart Grid 2010, 1, 205-212. [CrossRef]

67. Ipakchi, A.; Albuyeh, F. Grid of the future. IEEE Power Energy. Mag. 2009, 7, 52-62. [CrossRef]

68. Kanchev, H.; Lu, D.; Colas, F.; Lazarov, V.; Francois, B. Energy Management and Operational Planning of a Microgrid with a PV-Based Active Generator for Smart Grid Applications. IEEE Trans. Ind. Electron. 2011, 58, 4583-4592. [CrossRef]

69. Nguyen, C.P.; Flueck, A.J. Agent Based Restoration with Distributed Energy Storage Support in Smart Grids. IEEE Trans. Smart Grid 2012, 3, 1029-1038. [CrossRef]

70. Liu, H.; Jin, L.; Le, D.; Chowdhury, A.A. Impact of high penetration of solar photovoltaic generation on power system small signal stability. In Proceedings of the International Conference on Power System Technology (POWERCON), Hangzhou, China, 24-28 October 2010; pp. 1-7.

71. Shah, R.; Mithulananthan, N.; Sode-Yome, A.; Lee, K.Y. Impact of large-scale PV penetration on power system oscillatory stability. In Proceedings of the IEEE Power and Energy Society General Meeting, Minneapolis, MN, USA, 25-29 July 2010; pp. 1-7.

72. Noroozian, N.; Andersson, G. Damping of Power System Oscillations by Use of Controllable Components. IEEE Trans. Power Deliv. 1994, 9, 2046-2054. [CrossRef]

73. Galrmos, G.D.; Hatziadoniu, C.; Cheng, X.J.; Maratukuron, D. Advanced Static Compensation for Flexible AC Transmission. IEEE Trans. Power Syst. 1993, 8, 113-121.

74. Shah, R.; Mithulananthan, N. Interconnection of PV based generator and its impact on Bangladesh power system stability. In Proceedings of the International Conference on the Developments in Renewable Energy Technology (ICDRET), Dhaka, Bangladesh, 17-19 December 2009; pp. 1-6.

75. Yu, S.; Zhang, L.; Iu, H.H.; Fernando, T.; Wong, K.P. A DSE-Based Power System Frequency Restoration Strategy for PV-Integrated Power Systems Considering Solar Irradiance Variations. IEEE Trans. Ind. Inform. 2017, 13, 2511-2518. [CrossRef]

76. De Leon, F.; Boon-Teck, O. Damping power system oscillations by unidirectional control of alternative power generation plants. In Proceedings of the IEEE Power Engineering Society Winter Meeting 2001, Columbus, OH, USA, 28 January-1 February 2010; pp. 747-752.

77. Keyhani, A.; Chatterjee, A. Automatic Generation Control Structure for Smart Power Grids. IEEE Trans. Smart Grid 2012, 3, 1310-1316. [CrossRef]

78. Bevrani, H.; Ghosh, A.; Ledwich, G. Renewable energy sources and frequency regulation: Survey and new perspectives. IET Renew. Power Gener. 2010, 4, 438-457. [CrossRef] 
79. Datta, M.; Senjyu, T.; Yona, A.; Funabashi, T. Minimal-order observer-based coordinated control method for isolated power utility connected multiple photovoltaic systems to reduce frequency deviations. IET Renew. Power Gener. 2010, 4, 153-164. [CrossRef]

80. Yu, Y.N. Electric Power System Dynamics; Academic Press: London, UK, 1983.

81. Du, W.; Wang, H.; Xiao, L.-Y. Power system small-signal stability as affected by grid-connected photovoltaic generation. Eur. Trans. Electr. Power 2011, 22, 688-703. [CrossRef]

82. Shah, R.; Mithulananthan, N.; Lee, K.Y. Large-Scale PV Plant with a Robust Controller Considering Power Oscillation Damping. IEEE Trans. Energy Convers. 2013, 28, 106-116. [CrossRef]

83. Zhou, L.; Yu, X.; Li, B.; Zheng, C.; Liu, J.; Liu, Q.; Guo, K. Damping Inter-Area Oscillations with Large-Scale PV Plant by Modified Multiple-Model Adaptive Control Strategy. IEEE Trans. Sustain. Energy 2017, 8, 1629-1636. [CrossRef]

84. You, S.; Kou, G.; Liu, Y.; Zhang, X.; Cui, Y.; Till, M.J.; Yao, W.; Liu, Y. Impact of High PV Penetration on the Inter-Area Oscillations in the U.S. Eastern Interconnection. IEEE Access 2017, 5, 4361-4369. [CrossRef]

85. Datta, M.; Senjyu, T.; Yona, A.; Funabashi, T.; Kim, C.-H. A frequency-control approach by photovoltaic generator in a PV-diesel hybrid power system. IEEE Trans. Energy Convers. 2011, 26, 559-571. [CrossRef]

86. Alquthami, T.; Ravindra, H.; Faruque, M.O.; Steurer, M.; Baldwin, T. Study of photovoltaic integration impact on system stability using custom model of PV arrays integrated with PSS/E. In Proceedings of the North American Power Symposium (NAPS), Arlington, TX, USA, 26-28 September 2010; pp. 1-8.

87. Brown, M.; Stetz, T.; Reimann, T.; Valov, B.; Arnold, G. Optimal reactive power supply in distribution networks-Technological and economical assessment for PV-Systems. In Proceedings of the 24th European Photovoltaic Solar Energy Conference and Exhibition, Hamburg, Germany, 21-25 September 2009.

88. Tan, Y.T.; Kirschen, D.S. Impact on the Power System of a Large Penetration of Photovoltaic Generation. In Proceedings of the IEEE Power Engineering Society General Meeting, Galgary, AB, Canada, 24-28 June 2007; pp. 1-8.

89. Katiraei, F.; Mauch, K.; Dignard-Bailey, L. Integration of photovoltaic power system in high penetration cluster for distribution networks and mini-grids. Int. J. Distrib. Energy Resour. 2007, 3, 207-223.

90. Teleke, S.; Jahanbakhsh, F.; Katiraei, F.; Aguero, J.R. Analysis of interconnection of photovoltaic distributed generation. In Proceedings of the IEEE Industry Applications Society Annual Meeting (IAS), Orlando, FL, USA, 9-13 October 2011; pp. 1-6.

91. Canova, A.; Giaccone, L.; Spertino, F.; Tartaglia, M. Electrical Impact of Photovoltaic Plant in Distributed Network. IEEE Trans. Ind. Appl. 2009, 45, 341-347. [CrossRef]

92. Refaat, S.S.; Abu-Rub, H.; Sanfilippo, A.P.; Mohamed, A. Impact of grid-tied large-scale photovoltaic system on dynamic voltage stability of electric power grids. IET Renew. Power Gener. 2018, 12, 157-164. [CrossRef]

93. Brown, R.E.; Freeman, L.A. Analyzing the Reliability Impact of Distributed Generation. In Proceedings of the 2001 Power Engineering Society Summer Meeting, Vancouver, BC, Canada, 15-19 July 2001; pp. 1013-1018.

94. Chowdhury, B.H. Effect of central station photovoltaic plant on power system security. In Proceedings of the 21st IEEE Photovoltaic Specialist Conference, Kissimmee, FL, USA, 21-25 May 1990.

95. Kongtonpisan, S.; Chaitusaney, S. Impact of Grid-Connected Photovoltaic System on total system losses with consideration of capacitor bank setting using Genetic algorithm. In Proceedings of the 8th International Conference on Electrical Engineering/Electronics, Computer, Telecommunications and Information Technology (ECTI-CON), Khon Kaen, Thailand, 17-20 May 2011; pp. 885-888.

96. Aziz, T.; Dahal, S.; Mithulananthan, N.; Saha, T.K. Impact of widespread penetrations of renewable generation on distribution system stability. In Proceedings of the International Conference on Electrical and Computer Engineering (ICECE), Dhaka, Bangladesh, 8-10 September 2010; pp. 338-341.

97. Baghzouz, Y. Voltage Regulation and Overcurrent Protection Issues in Distribution Feeders with Distributed Generation-A Case Study. In Proceedings of the 38th Hawaii International Conference on System Sciences, Big Island, HI, USA, 3-6 January 2005.

98. Shang, Y. Resilient Multiscale Coordination Control against Adversarial Nodes. Energies 2018, 11, 1844. [CrossRef]

99. Lim, S.H.; Kim, J.S.; Kim, M.H.; Kim, J.C. Improvement of Protection Coordination of Protective Devices Through Application of a SFCL in a Power Distribution System with a Dispersed Generation. IEEE Trans. Appl. Supercond. 2012, 22. 
100. Fusco, F.; Nolan, G.; Ringwood, J.V. Variability reduction through optimal combination of wind/wave resources-An Irish case study. Energy 2010, 35, 314-325. [CrossRef]

101. Rafique, S.F.; Zhang, J. Energy management system, generation and demand predictors: A review. IET Gener. Transm. Distrib. 2018, 12, 519-530. [CrossRef]

102. Dokopoulos, P.S.; Saramourtsis, A.C.; Bakirtzis, A.G. Prediction and evaluation of the performance of wind-diesel energy systems. IEEE Trans. Energy Convers. 1996, 11, 385-393. [CrossRef]

103. Byun, J.; Hong, I.; Kang, B.; Park, S. A Smart Energy Distribution and Management System for Renewable Energy Distribution and Context-aware Services based on User Patterns and Load Forecasting. IEEE Trans. Consum. Electron. 2011, 57. [CrossRef]

104. Boehme, T.; Wallace, A.R.; Harrison, G.P. Applying Time Series to Power Flow Analysis in Networks with High Wind Penetration. IEEE Trans. Power Syst. 2007, 22, 951-957. [CrossRef]

105. Kramer, O.; Gieseke, F. Analysis of wind energy time series with kernel methods and neural networks. In Proceedings of the Seventh International Conference on Natural Computation (ICNC), Shanghai, China, 26-28 July 2011; Volume 4, pp. 2381-2385.

106. Nejabatkhah, F.; Danyali, S.; Hosseini, S.H.; Sabahi, M.; Niapour, S.M. Modeling and Control of a New Three-Input DC-DC Boost Converter for Hybrid PV/FC/Battery Power System. IEEE Trans. Power Electron. 2012, 27, 2309-2324. [CrossRef]

107. Pelacchi, P.; Poli, D. The influence of wind generation on power system reliability and the possible use of hydrogen storages. Electr. Power Syst. Res. 2010, 80, 249-255. [CrossRef]

108. Ilic, M.; Black, J.W.; Prica, M. Distributed electric power systems of the future: Institutional and technological drivers for near-optimal performance. Electr. Power Syst. Res. 2007, 77, 1160-1177. [CrossRef]

109. Kato, T.; Inoue, T.; Suzuoki, Y. Impact of large-scale penetration of photovoltaic power generation systems on fluctuation property of electricity load. In Proceedings of the IEEE PES Transmission and Distribution Conference and Exposition, São Paulo, Brazil, 8-10 November 2010; pp. 1-6.

110. Morjaria, M.; Anichkov, D.; Chadliev, V.; Soni, S. A Grid-Friendly Plant: The Role of Utility-Scale Photovoltaic Plants in Grid Stability and Reliability. IEEE Power Energy Mag. 2014, 12, 87-95. [CrossRef]

111. Shahidirad, N.; Niroomand, M.; Hooshmand, R.A. Investigation of PV Power Plant Structures Based on Monte Carlo Reliability and Economic Analysis. IEEE J. Photovolt. 2018, 8, 825-833. [CrossRef]

112. Eriksson, R.; Modig, N.; Elkington, K. Synthetic inertia versus fast frequency response: A definition. IET Renew. Power Gener. 2018, 12, 507-514. [CrossRef]

113. Beck, H.P.; Hesse, R. Virtual synchronous machine. In Proceedings of the EPQU, Barcelona, Spain, 9-11 October 2007; pp. 1-6.

114. Hesse, R.; Beck, H.; Turschner, D. Conditioning Device for Energy Supply Networks. US8510090B2. 2007.

115. Gao, F.; Iravani, M.R. A control strategy for a distributed generation unit in grid-connected and autonomous modes of operation. IEEE Trans. Power Deliv. 2008, 23, 850-859.

116. Van Wesenbeeck, M.P.N.; de Haan, S.W.H.; Varela, P.; Visscher, K. Grid tied converter with virtual kinetic storage. In Proceedings of the IEEE PowerTech, Bucharest, Romania, 28 June-2 July 2009; pp. 1-7.

117. Vrana, T.K.; Hille, C. A novel control method for dispersed converters providing dynamic frequency response. Electr. Eng. 2011, 93, 217-226. [CrossRef]

118. Rodriguez, P.; Candela, J.I.; Rocabert, J.; Teodorescu, R. Synchronous Power Controller for a Generating System Based on Static Power Converters. International Patent WO 2012/117 131 A1, 7 September 2012.

119. D'Arco, S.; Suul, J.A.; Fosso, O.B. Control system tuning and stability analysis of Virtual Synchronous Machines. In Proceedings of the 2013 IEEE Energy Conversion Congress and Exposition (ECCE 2013), Denver, Colorado, 15-19 September 2013; pp. 2664-2671.

120. Zhong, Q.C.; Weiss, G. Synchronverters: Inverters that mimic synchronous generators. IEEE Trans. Ind. Electron. 2011, 58, 1259-1267. [CrossRef]

121. Sakimoto, K.; Miura, Y.; Ise, T. Stabilization of a power system with a distributed generator by a Virtual Synchronous Generator function. In Proceedings of the ICPE 2011-ECCE Asia, Jeju Island, Korea, 30 May-3 June 2011; pp. 1498-1505.

(C) 2019 by the authors. Licensee MDPI, Basel, Switzerland. This article is an open access article distributed under the terms and conditions of the Creative Commons Attribution (CC BY) license (http://creativecommons.org/licenses/by/4.0/). 